\title{
The Evolving Military Learner Population: A Review of the Literature
}

\author{
Kate Ford, Karen Vignare \\ University of Maryland University College
}

\begin{abstract}
This literature review examines the evolving online military learner population with emphasis on current generation military learners, who are most frequently Post-9/11 veterans. The review synthesizes recent scholarly and grey literature on military learner demographics and attributes, college experiences, and academic outcomes against a backdrop of conceptual frameworks addressing adult transition theory, learner persistence, and institutional responsiveness. Military learner demographics and academic risk profiles are most similar to nontraditional, first generation learners, although military learners face additional challenges associated with service-connected injuries and disabilities. Like other nontraditional learners juggling work, family, and academic responsibilities, military learners have become increasingly reliant on online learning. Intersecting community memberships, role identities, and commitments often complicate the transition to college and perceived sense of fit, a finding more pronounced in studies involving military learners attending campuses predominately serving traditional students. The significant lack of research examining online military learners limited further comparative analysis.
\end{abstract}

\section{Introduction}

Overall, current research suggests military learners adapt and persist in college by drawing upon deeply engrained military traits and tendencies, including self-discipline, mission-first focus, and reliance on fellow military learners. A few studies have suggested that institutional support systems for military learners, such as offering customized services and courses online, contributed to learner satisfaction and persistence. A growing number of institutions have adopted military-friendly approaches to program and service delivery since the enactment of the Post-9/11 GI Bill in 2008. Yet impact findings were mostly anecdotal. Confirming these findings requires additional quantitative empirical research with larger and more precisely defined population samples. As technology continues to blur previously sharp distinctions between face-to-face and online learning, the next wave of military learner research must focus on military learner retention models encompassing multiple learning modes and delivery methods, institutional student supports needed to enhance success, understanding military learner paths through multiple institutions and population samples that provide generalizable information about military learners. 


\section{Review of the Literature}

This literature review examines the recent scholarly and grey literature published between 20002014 on current generation military learners and their related college experiences and outcomes with an emphasis on the Post-9/11 military learner, who is most often a student veteran. Military learners, like nontraditional learners, increasingly select education offerings in online learning formats (Allen \& Seaman, 2011, 2013). There is still a lack of research about online military learners and this special issue will begin to address research needed on military student populations. This literature review attempts to connect the literature on military students with research on online learners. The review is by no means exhaustive. Rather, it is an attempt to distill and synthesize the representative findings of current research against a backdrop of conceptual frameworks addressing adult transition theory, learner persistence and institutional responsiveness.

Each year, an average of 300,000 degree-seeking active-duty service members attend college courses on base, off-base, or online using tuition assistance benefits available through the Department of Defense's Voluntary Education Program (Military OneSource, 2014). The largest military-serving institutions all recognize that the pattern of attendance has been shifting from active duty to veteran. Tuition assistance expenditures reported by the Department of Defense each year have been proportionally higher for distance learning compared to classroom learning, suggesting that more activeduty service members are taking college courses online rather than in traditional classroom settings (DOD voluntary education fact sheets, FY2009-FY2013). Annual Veteran Benefits Administration Performance and Accountability Reports (http://www.benefits.va.gov/reports/annual_performance_reports.asp) have shown steady annual increases in the total number of GI Bill beneficiaries for more than a decade. For example, in 2001, the total number of beneficiaries across all available GI Bill chapters, excluding Survivor and Dependent Assistance, was 373,734. By 2008, that number climbed to 461,248. By 2012, the number nearly doubled to 845,094, with the largest percentage gain attributable to an influx of veterans receiving benefits through the Post-9/11 Veterans Educational Assistance Act of 2008, or Post9/11 GI Bill.

Enacted in 2008, the Post-9/11 GI Bill significantly expanded educational benefits available to qualifying military veterans who served at least 90 days of active duty following September 11, 2001. The new bill covered tuition, payable directly to the institution where the beneficiary enrolled, at up to $100 \%$ of the highest public in-state undergraduate tuition for 36 months. The bill also provided an annual book stipend up to $\$ 1,000$ and a housing allowance directly to the learner. Unlike previous GI Bills, the Post9/11 GI Bill also contained a provision allowing veterans to transfer unused benefits to their spouses or children. Additional enhancements enacted since 2008 increased the number and type of covered educational expenses, streamlined the maximum tuition cap (\$20,235.02 for 2014-15), expanded benefits to qualifying members of the National Guard and reserves, and extended a pro-rated housing allowance to veterans pursuing all of their courses online (Veterans Benefits Administration, 2014). By comparison, the Montgomery GI Bill for veterans who served on active duty (MGIB-AD) required a longer period of qualifying service and an individual contribution of $\$ 100$ per month for the first 12 months of duty. A single monthly benefit check was paid directly to student veterans. The total maximum monthly benefit in 2008 was $\$ 1,101$, which typically covered less than $75 \%$ of the average cost of tuition, fees, room and board at four-year public universities and only about 30\% at private four-year institutions. The maximum monthly education benefit available to members of the reserves and National Guard under the Montgomery GI Bill-Selected Reserve (MGIB-SR) and the Reserve Educational Assistance Program (REAP) was significantly less (Smole \& Loane, 2008).

The Post-9/11 GI Bill has fueled a growing interest in the college experiences and outcomes of the current generation military learner, although much of the current research focuses primarily on the student veteran rather than service members who are still on active duty. The amount of peer-reviewed empirical research remains rather limited (Barry, Whiteman, \& MacDermid Wadsworth, 2014). 
Nevertheless, a tentative and informative body of knowledge awaits the researcher willing to expand the search to include non-peer-reviewed and practitioner-based journals, government data sources, informed commentary from higher education associations and think tanks, and the significant number of quality doctoral dissertations documenting the lived experiences of the military learner. However, the lack of attention paid to military learners who predominately pursue their degrees online represents a major failing in the current research, particularly given statistical enrollment information suggesting that military learners are more likely than both traditional learners and nontraditional learners to complete at least part of their degree online (National Survey of Student Engagement, 2010; Radford, 2011). This review begins with a profile of the Post-9/11 military learner and synthesis of literature describing the military learner's movement through and adaptation to higher education learning environments. The institutional response or adaptation to the military learner is explored next, followed by a discussion of the data on military learner outcomes.

\section{Method}

The exploratory research performed for the literature review was grounded by four research questions:

1. What are the documented educational outcomes of current generation military learners?

2. What are the demographic characteristics and college experiences of current generation military learners?

3. Are there individual or group attributes associated with military learners that have been found to positively or negatively correlate with or influence outcomes such as academic performance, persistence and degree attainment?

4. What are institutions doing to support military learner success and degree attainment?

Multiple disciplines and perspectives were considered, including educational psychology, philosophy, sociology and higher education/distance learning. For the initial review, various key words, including transition, acculturation, academic efficacy, self-regulated learning, persistence, retention, outcomes and student services were combined with the term military learner in a search engine available through the University of Maryland University College (UMUC) online library services. The search engine simultaneously scans more than one hundred online databases, including, but not limited to, ERIC, Academic Search Complete, Military and Government Collection, Psychology and Behavior Sciences Collection, PubMed, Survey of Distance Learning Programs in Higher Education 2012-13 Edition and SocINDEX with Full Text.

When the initial search of scholarly literature revealed a rather limited body of knowledge relative to the specific research questions used for this review, it was expanded to include additional citations from select articles, dissertations and other types of relevant grey literature available in full-text format from UMUC's library databases, Google Scholar and Google Search. The combined search of the scholarly and grey literature yielded two somewhat distinct, although not mutually exclusive themes related to current generation military learners. The first theme pertained primarily to the participation, persistence and outcomes of active-duty service members pursuing voluntary/off-duty higher education courses, primarily in face-to-face classroom settings. The second more voluminous theme emerged in 2008 and primarily addressed current generation student veterans entering or returning to college following active-duty status. This theme explored college transition and integration, health and disability needs related to combat exposure, postsecondary institution programs and services targeting service members and veterans, and-to a lesser extent-quantifiable academic outcomes. The majority of resources associated with both themes failed to address the military learner in the context of online learning environments. 
The current scholarly and grey literature on military learners was inconsistent in the usage of terms such as student veteran, service member or military undergraduate. Some studies have used the term student veterans broadly to refer to all military-affiliated members of a student population, regardless of whether their status was active, retired or reserve. The lack of precision in terminology has also been documented by Cate (2014b) and Barry, Whiteman, and Macdermid Wadsworth (2014). For clarification purposes, the term military learner is used throughout this review to refer to members of the military student population enrolled in postsecondary higher education who are: a) active-duty service members; b) National Guard members; c) reservists; and d) veterans. Findings that apply only to a specific subset of military learners are noted. While also worthy of study, particularly given the transferability of Post-9/11 GI Bill benefits, spouses and dependents of military learners are beyond the scope of this review. The phrase current generation military learner refers broadly to those who served in the United States Armed Forces between 1990 and the present. This period encompasses the first Gulf War (Operations Desert Shield and Desert Storm) through the more recent surges and withdrawal of troops in the Middle East:

- Operation Enduring Freedom (OEF), the U.S. military mission in Afghanistan that commenced on October 7, 2001.

- Operation Iraqi Freedom (OIF), which commenced on March 20, 2003, with draw down of troops in December 2011.

- Operation New Dawn (OND), the terminology used by Department of Defense to describe the military presence in Iraq after September 1, 2010.

Post-9/11 military learner refers specifically to current generation military learners who were engaged in military service after September 2001.

When comparisons were drawn in the literature between military learners and other learners, the terms traditional and nontraditional are most often used. Traditional typically refers to learners under the age of 24 attending college full time who are not financially independent for financial aid purposes. The National Center for Education Statistics (NCES) provides a more complete definition of nontraditional learners as possessing one or more of the following defining attributes, which have also been found to increase the risk of not completing college (Choy, 2002; Horn \& Carroll, 1996):

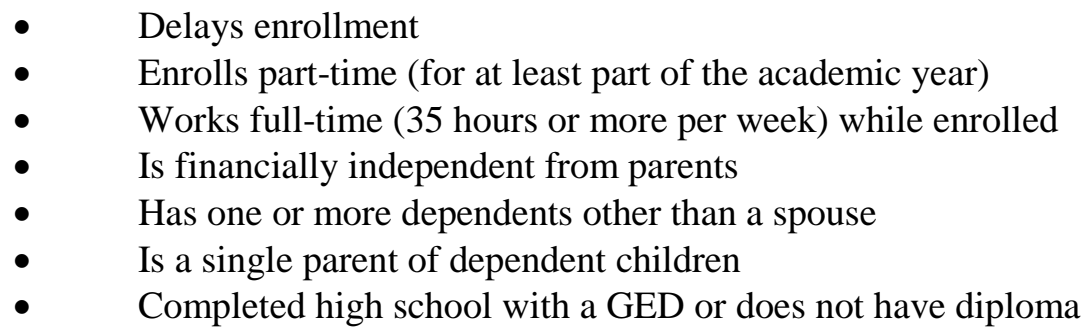

Horn and Caroll's (1996) description of learners on a continuum based on their number of nontraditional characteristics provides a useful framework for understanding the military learner demographic profile. Whereas a traditional learner possesses none of the seven characteristics associated with nontraditional learners, a minimally nontraditional military learner possesses one, a moderately nontraditional learner possesses two to three and a highly nontraditional military learner possesses four or more characteristics.

In cases where the traditional/nontraditional status of non-military learners is not clear from the literature, this review employs the term nonmilitary learner. As a group, military learners were generally viewed as nontraditional learners, although some individual military learners possessed demographic characteristics or enrollment patterns more closely associated with those of traditional learners. Caution is advised when generalizing any findings beyond the setting in which they occurred. 
The Evolving Military Learner Population: A Review of the Literature

\section{Organizing Framework}

Theoretical models that describe input, environmental, and output variables are useful for conceptualizing the process or path through which learners enter, engage, and ultimately complete or dropout of college. The most frequently observed models or frameworks in the literature analyzed for this review explain, theoretically, adult transition or student integration and persistence (Bean \& Metzner, 1985; Schlossberg, 1984; Schlossberg, Lynch, \& Chickering,1989; Tinto, 1993, 1997, 2006). This finding was not surprising. Much of the current literature specifically examines: a) the transitional experiences of military learners from the highly structured and regimented culture of the military to the more ambiguous and self-regulated environment associated postsecondary education; b) military learners' college experiences and obstacles; and c) the resulting sense of belonging or fit, intent to persist, or, to a lesser extent, specific academic outcomes and completion rates (Barnhart, 2011, Beatty, 2013; Carne, 2011; Covert, 2002; Diamond, 2012; DiRamio, Ackerman, \& Mitchell, 2008; DiRamio \& Jarvis, 2011; Dunklin, 2012; Hayek, 2011, Lang \& Powers, 2013; Lemos, 2013; Livingston, 2009; Lopez, 2013; O’Rourke, 2013; Rumann, 2010; Rumann \& Hamrick, 2010; Wilson, Smith, Lee, \& Stevenson; 2013).

According to Schlossberg (1984), transitions are significant when they challenge and transform roles, relationships, beliefs, or the customary manner in which things are done. Adult transition theory posits that there are four types of transitional triggers or events: planned, unplanned, nonevent, and chronic hassle. In the context of a military learner, a planned transition is retiring from military service and enrolling in college. Being discharged early as a result of a combat injury or service-connected disability is an unplanned transition. Planning for a deployment that does not occur is a nonevent. An inability to focus during lectures or exams because of a traumatic brain injury is an example of a chronic hassle. Schlossberg, Lynch, and Chickering (1989) described transitions as a multi-stage process that one moves in, through, and out. Their 4S model encompassing situation, self, supports and strategies described how the individual navigates the transition by taking stock of the situation and the available coping resources.

The seminal persistence and attrition models developed by Tinto (1993) and Bean and Metzner (1985) also speak to the military learner's transition to college, although the conceptual focus of these models is primarily on the subsequent engagement and support factors believed to influence college persistence or attrition. Tinto's model originally focused on the successful academic and social integration of traditional learners as a pre-condition for avoiding college departure. In 1997, Tinto updated the theoretical language and construct of the model to incorporate differences found in the academic engagement profile for nontraditional learners. Central to these revisions was an emphasis on the centrality of the classroom in fostering the academic and social integration of both traditional and nontraditional learners, making the model somewhat more useful in framing the persistence of military learners. Bean and Metzner's model (1985) built on previous models by retaining the background and academic integration variables expected to impact retention for nontraditional learners-who were defined as being older (age 25 or over), part-time commuter learners - while addressing the larger impact of the external environment. Their model theorized that positive environmental support variables compensated for poor academic support, but that poor environmental variables outweighed positive academic variables in the decision to leave.

One of the shortcomings of the aforementioned persistence/attrition models is the assumption that a university is a single node end-state with persistence or departure as the only two possible outcomes. As a result, the models do not adequately account for the mobility or migration patterns of military learners that may result in multiple college transfers or the deployment-related stop-outs of current generation military learners. These models were developed prior to the proliferation of online learning environments. They do not account for military learner persistence in online learning environments, according to Hayek (2011), whose research called into question Bean and Metzner's conceptual model of nontraditional student attrition. 
Military learners were more likely to be first generation college learners from lower income families, online learners and learners whose persistence patterns do not follow the terminal departure endstate depicted in older persistence models (Cole \& Kim, 2013; National Survey of Student Engagement, 2010; Radford, 2011). Therefore, an alternative persistence model was chosen as the primary conceptual framework for this review. First proposed by Falcone (2011) and subsequently updated by Shea and Bidjerano (2014) to include technology-enabled institutional responsiveness to the learner, this comprehensive persistence model addresses factors believed to influence the college persistence of lowincome, low-socioeconomic status, first-generation and working class learners.

Multiple theoretical perspectives are embedded in the model, including elements of Tinto's attrition model, Rendon's (1994, 2002) theory of validation, and Bourdieu's concepts (1977a, 1977b, 1984, 1986) of social structural forces, individual agency, and forms of capital. Bourdieu (1986) identified three types of capital: economic, social and cultural. Economic capital is material wealth. In the context of the military learner, GI Bill benefits represent economic capital the veteran has earned in exchange for a specified period of military service. A student veteran converts that capital to cash value by drawing down his or her benefits to pay for tuition, books and housing. One's connections represent social capital. The ability to draw value from those connections is situational. For example, the value of the camaraderie and esprit de corps associated with military service is never clearer than on the battlefield where survival and completion of the mission depend heavily on deep team cohesion and willingness to make personal sacrifices. Building and drawing value from social connections outside the military requires learning different situational-appropriate tactics. According to Bourdieu, cultural capital can be objectified, institutionalized or embodied, and may also be converted to economic capital. Objectified cultural capital includes paintings, books, machines or other symbolic artifacts representing one's knowledge, talents, skills, status, etc. Institutionalized cultural capital is a form of objectified capital that confers and conveys additional meaning beyond the object properties. Examples of institutionalized cultural capital include military uniforms, stripes, stars or medals representing affiliation, rank, authority and performance. A college degree is another institutionalized form of cultural capital. Embodied cultural capital is acquired through socialization and education. It represents the internalization of external capital, or habitus - the deeply engrained dispositions that govern one's attitudes and actions. Habitus can generally be thought of as the product of one's upbringing. One can argue that the nature of military indoctrination, training, and socialization is such that a military learner's habitus may be more reflective of the deeply engrained values and behaviors prized by the military than of his or her upbringing.

The use of a multi-theoretical model to frame college learner persistence responds to the recommendations of several retention researchers who posited that existing theoretical models fail to adequately address the complexity of college persistence, particularly for marginalized or nontraditional learner populations (Braxton \& Milem, 2000; Park \& Choi, 2008; Rovai, 2003; Wapole, 2007). One can further argue that the conceptual underpinnings of Falcone's model (2011) operate in a complimentary manner to key elements of the adult transition model, namely self, situation, support and strategies (Schlossberg et al., 1989). While adult transition theory primarily concerns itself with the individual's perspective taking and coping processes during major transitions, the interplay between individual perception, agency, and social context is apparent in both Falcone's persistence model (2011) and the 4S model. As can be seen in Figure 1, Shea and Bidjerano's (2014) insertion of an institutional adaptation portfolio node within the environmental and experiential variables section of Falcone's model extends the model's usefulness as a framework for examining the institutional response to military learners and responded to what Tinto (2006) described as the absence of an effective and sustainable multi-layered model of institutional action. Shea and Bidjerano (2014) move the field further by including the institutional role in the retention process. The military learner still transitions frequently, so additional conceptual modeling is required to understand whether the role of the institution and its responsiveness is the only factor at play, or whether military culture-which is characterized by frequent changes in mission, purpose, and location — plays a foundational role in educational goals. 


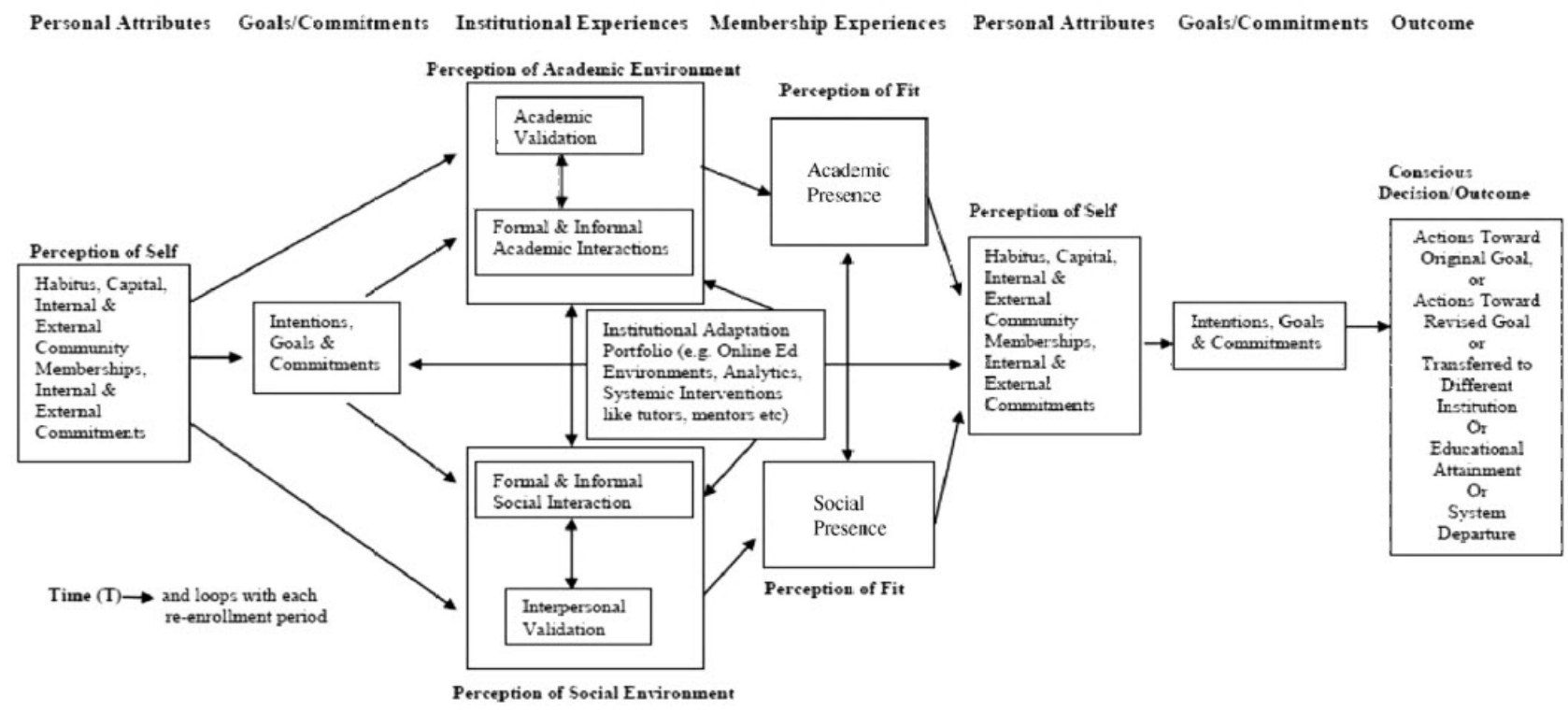

Figure 1: Falcone's (2011) student persistence model updated by Shea and Bidjerano to reflect technology-enabled institutional adaptation to the learner. From Shea, P. \& Bidjerano, T. (2014). Does online learning impede degree completion? A national study of community college students. Computers \& Education, 75, p.110. Copyright 2014 by Elsevier. Reprinted with permission.

\section{Results}

\section{Profile of Current Generation Military Learners}

Some of the most frequently cited demographic data on current generation military learners comes from two national data sets that are somewhat dated, namely the National Center for Education Statistics (NCES) 2004/09 Beginning Postsecondary Students Longitudinal Study (BPS: 04/09) and the 2007-2008 National Postsecondary Student Aid Study (NPSAS:08) (Radford 2009; Radford \& Wun, 2009; Radford, 2011). This data represents a cohort of military learners who entered higher education just prior to the implementation of the more generous Post-9/11 GI Bill. The NPSAS:08 dataset showed that military learners represented approximately $4 \%$ of the total student population enrolled in higher education, with veterans significantly outnumbering active-duty service member enrollments (Radford \& Wun, 2009).

Overall, military learners were more similar to nontraditional learners in that they were typically age 24 or older; juggling family, work, and academic responsibilities; and more likely to be enrolled parttime. Nevertheless, military learners spent as much time studying as traditional learners, despite working more hours and spending more time on family responsibilities each week (National Survey of Student Engagement, 2010).

Military learners received financial aid awards and GI Bill benefits that were comparable to or larger than those received by nontraditional learners, with for-profit institutions most often awarding the highest amount of aid, typically in the form of loans (Radford \& Wun, 2009). These findings are consistent with a small sample study by Cate (2011), in which all respondents reported using financial aid to pay for college, with $60 \%$ using multiple forms of aid, including GI Bill benefits, grants and scholarships. Almost half of the respondents reported also using personal savings and federal loans.

Military learners were also similar to other nontraditional learners in their choice of college. Military learners enrolled more often at community colleges and private for-profit institutions than traditional undergraduates. While for-profits and community colleges draw more nontraditional than traditional learners, all nontraditional learners, both military and nonmilitary, were enrolled more often at 
four-year public institutions than for-profit institutions (Radford, 2011). Consistent with earlier national datasets, preliminary NCES data for the fall 2012 semester indicated that undergraduate military learners enrolled most often in public two-year institutions, followed by public four-year institutions. The more recent data indicated that more undergraduate military learners enrolled at private for-profit rather than private non-profit four-year institutions, although graduate military learners attended private non-profit institutions more often (followed by public institutions) than private for-profit institutions (Queen \& Lewis, 2014). A recent report by the U.S. Senate Health, Education, Labor, and Pensions Committee indicates that the total number of veterans attending private for-profit institutions using the Post-9/11 GI Bill has increased from 23\% in 2009 to 30\% in 2013 (Harkin, 2014). The number of veterans choosing for-profit institutions has increased quickly in the Post-9/11 era.

Nationally, military learners most frequently cited location, affordability, and available degree programs as key drivers in their choice of college; nonmilitary nontraditional learners also indicated college reputation as a factor (Radford, 2011). A smaller study of military learners across multiple institutions in Arizona, Virginia and Ohio, found that military learners who attended private non-profit and public institutions also cited reputation of the institution and its degree programs as deciding factors. Participants in that study who attended for-profit institutions indicated that the focus on adult learners, convenient class hours and the availability of campus locations in multiple states were among the most important considerations (Steele et al., 2010). Another small study found that college choice for activeduty service members pursuing their degrees online was closely related to their military work experiences and career paths (Bunting, 2003).

Although the data pointed to a number of similarities between military learners and other nontraditional learners, there were also some noteworthy differences (Radford, 2011). Military undergraduates were more likely to pursue degrees in technical fields and enroll in distance education courses, the majority of which used asynchronous Internet-based technologies. They were also less likely to have a dependent or be single parents than other nontraditional undergraduate learners. Slightly less than one-third of military undergraduates attended college full-time the entire year, but that rate is still higher than the number of nontraditional learners attending full time (Radford, 2011). This difference may be explained in part by the availability of GI Bill benefits, because the data analyzed by Radford also indicated military learners who received those benefits were more likely to maintain full-time enrollment status throughout the year than those who did not receive benefits. At the graduate level, military learners were more often over the age of 35 and waited longer than other graduate students - seven years on average-before starting graduate school. Graduate military learners were also more likely to be African American, less likely to be Asian, more likely to be married with dependents, and more likely to enroll in online learning courses than their nonmilitary peers (Parsad \& Lewis, 2008; Radford, 2011).

More recent demographics compiled by the Department of Veterans Affairs (2014) indicated that $73 \%$ of military learners were male and $27 \%$ were female. Slightly less than half were married and/or had children. The majority of military learners were $24-40$ years old, although $15 \%$ fell within the same age range (18-24) as traditional college learners. Also, 62\% of military learners were first generation learners. These statistics are largely consistent with those reported by the National Survey of Student Engagement (2010), which also indicated that military learners were also more likely to be transfer students.

Consistent with Falcone’s (2011) persistence model, Wurster, Rinaldi, Woods, \& Liu (2013) argued that being a first generation learner adds significantly to the persistence complexities of student veterans. They identified numerous persistence risk factors from the literature on first generation learners likely to also affect student veterans:

- $\quad$ Delaying college enrollment

- $\quad$ Coming from lower income family backgrounds

- Having dependents

- $\quad$ Living off-campus 
- Working full-time while attending school

- $\quad$ Being less prepared, academically

- $\quad$ Having lower education aspirations

- $\quad$ Lacking knowledge on navigating the application and enrollment process

- Lack of financial, informational, and embodied cultural capital associated with having parents who attended college

Wurster et al. further posited that differences in the types of cultural and social capital valued by the military versus academia may increase the difficulty student veterans experience in adjusting to the college environment.

Another key difference between nonmilitary learners and military learners is the latter's exposure to combat activity during Operation Enduring Freedom (OEF) and Operation Iraqi Freedom (OIF) and the impact of what Schlossberg (1984) would classify as a chronic hassle type of transition associated with combat-related physical and mental health injuries. Numerous studies and reports identified the following wounds as prevalent among service members returning from OEF/OIF: Traumatic Brain Injury (TBI), PTSD, depression, loss of limbs, orthopedic injuries, severe burns, and hearing loss (Barry, Whiteman, \& Macdermid Wadsworth, 2012; Cate, 2011; Church, 2009; Hoge, Castro, Messer, McGurk, Cotting, \& Koffman, 2004; Ness \& Vroman, 2014; Tanielian \& Jaycox, 2008; Vance \& Miller, 2009). The studies also indicated that the nature of the injury, severity of symptoms or side effects from treatment and medication may present numerous functional impairments or physical, emotional and cognitive challenges, which in turn, may also impact the learner's interactions, experiences and academic performance, both online and in face-to-face classrooms.

For example, those with spinal cord/back injuries, amputations and other conditions that limit physical dexterity may have difficulty sitting at a computer for an extended period of time or engaging in some computer related tasks. Sensory impairments may make it difficult for the learner to access a course website or electronic resources. Cognitive and psychological injuries may impair focus, memory, concentration and/or the ability to interpret feedback or organize and prioritize assignments (Church, 2009). Studies found military learners with service-connected disabilities may avoid treatment, disclosure and utilization of available services on or off campus (Cate, 2011; Church, 2009). Researchers have also documented increased rates of excessive alcohol consumption, binge drinking and substance abuse among student veterans, although they are more likely to engage in these behaviors as coping mechanisms rather than as socially motivated behaviors (Cate, 2011; Whiteman \& Barry, 2011).

As a result of their military training and experiences, military learners may also have greater selfdiscipline, leadership abilities, time-management skills, maturity and a sense of purposeful focus compared to traditional learners (Steele et al., 2010). These attributes, engrained through military socialization, represent Bourdieu's (1986) concepts of habitus and capital, which the learner can employ to mitigate the potential impact of the aforementioned challenges. Cate (2011) found military learners who perceived that they had high levels of social support were also less likely to experience negative life events post-deployment, although the majority of respondents in his study reported not being able to communicate or discuss problems with family or friends who could not relate to their military experiences. In keeping with the theoretical underpinnings of Falcone's (2011) persistence model and Schlossberg's (1984) adult transition theory, one can argue the lack of perceived support represents a deficit—one that may compel the learner to identify other internal/external memberships, which may provide the necessary level of support and validation. The extent to which military learners' attributes or external and internal memberships and commitments helped or hindered interactions, experiences and perceptions of fit with the institution is explored further in the next section.

The profiles of military learners are nearly as diverse as all higher education learners. The general demographics of military learners indicate they are more similar to nontraditional college learners even though a small percentage are younger than 25 years old. They choose colleges that nontraditional 
learners do and have a greater reliance on online and for-profit universities compared to traditional learners. They face the same risk factors as all nonmilitary nontraditional first generation learners, often combined with medical and mental challenges borne from being in combat and battlefield roles. Even when these additional risk factors are not a burden, military learners still face regular and significant transitions while attending college.

\section{Institutional Experiences}

Following the conceptual framework from Schlossberg (1984) and Falcone (2011), the military learner's stocktaking of self and situation were expected to have influenced his or her goals, commitments, and intentions - e.g., whether to attend college, choice of college, and field of study. Rate of pursuit and/or learning mode (online, hybrid, or classroom) decisions may have also been made, in accordance with the learner's perception of his or her work/life situation, available financial aid, whether he or she is re-enrolling after a deployment stop-out, enrolling for the first time or transferring with or without break.

\section{Enrollment and registration}

The military learner's first formal interaction with the institutional environment has been frequently portrayed in the literature as a battle with the bureaucracy, with the learner having to navigate an array of complexities associated with the admission, enrollment and financial aid processes. Some first-time military learners reported that the transition support received from the military, the Veterans Administration, and their chosen institutions-particularly in terms of accessing GI Bill or Department of Defense Tuition Assistance benefits-was not very helpful. Some received regular nonpayment/disenrollment notices while waiting for benefits to be processed. Others were surprised to learn that they did not qualify for the benefits under the Montgomery GI Bill or the initial version of the Post9/11 GI Bill (DiRamio et al., 2008; Steele et al., 2010).

Other common issues reported included unresponsive or indifferent staff, problems with forms and paperwork, benefit delays, difficulty navigating course schedules and registration processes, lack of veteran-specific services or social activities and interaction opportunities for veterans, and lack of handicapped parking (DiRamio et al., 2008; Elliott, Gonzalez, \& Larsen, 2011; Livingston, 2009; Lopez, 2013; Zinger \& Cohen, 2010). A number of military learners who were re-enrolling following deployments also reported encountering problems navigating one or more processes. For some, re-entry was further complicated by the way their withdrawals (for OEF/OIF deployments) had been processed, having their email or login accounts to other systems cancelled, or having to adjust their degree plans to account for having missed infrequently offered courses while deployed (Bauman, 2009; Beatty, 2013; DiRamio et al., 2008; Persky \& Oliver, 2010; Rumann \& Hamrick, 2010). Bean and Metzner (1985) point out that nontraditional learners face similar barriers when returning to college.

Another perspective expressed in the literature was an acute sense of pressure related to time. Some active-duty service members pursued their degrees entirely online, not because they perceived the courses as requiring less study time, but rather for the flexibility online learning afforded them in managing their time. They also found that online courses were less frequently cancelled (Bunting, 2003). Military learners enrolling for the first time and those re-enrolling following a deployment related stop out, often felt as though they had to make up for lost time or that they were behind their former peers who had completed their degree requirements and graduated. Some indicated that online learning enabled them to better manage their learning time around family and work responsibilities and indicated they would take all of their courses online were it not for the reduced housing allowance afforded to online learners under the Post-9/11 GI Bill. Others were concerned about supporting their families or running out of GI Bill benefits before being able to complete their studies. Their sense of urgency was exacerbated by the need to complete developmental education courses, and the limited availability of required courses, 
particularly during the summer months, as the rate of pursuit affected housing allowances (Rumann \& Hamrick, 2010; Steele et al. 2010).

One of the earliest interactions through which an institution can demonstrate sensitivity to the military learner's sense of urgency and provide a sense of validation is the credit transfer process (Carne, 2011; Steele et al., 2010). Institutions that are part of the Servicemembers Opportunity Colleges Consortium (SOC) agree to military-friendly practices with regard to accepting transfer credits from other institutions and awarding credit for military training based on the American Council on Education (ACE) guidelines. Some studies indicated that military learners were disappointed with this process. Some expressed frustration with non-standardized processes in which the decision to award credit was left to the discretion of individual academic departments. Others found themselves repeating coursework because the awarded credit did not count toward their degree requirements.

\section{Academic and social interactions}

Beyond the interactions with institutional business processes, the military learner's formal and informal interactions and experiences with faculty and other learners were also a source of potential academic and interpersonal validation influencing the learner's perception of "institutional fit" or sense of belonging. Most of the literature did not include online military learners. The literature revealed several examples of military learners feeling disrespected by their instructors. Some learners reported that an instructor spoke or acted in a way they perceived as hostile towards the military. Others indicated some instructors were insensitive to their ongoing military duty requirements. Some classroom instructors were also seen as being insensitive to the military learner's desire not to be singled out in class, either for special treatment, or as a "spokesperson" for the military during class discussions. Other examples provided by online military learners and those in campus classrooms spoke more to the lack of expected instructional presence and structure. Notwithstanding these examples, many military learners indicated they found their instructors, particularly those with military experience, to be helpful, accommodating, and approachable in-class and outside of class (Cate, 2011; DiRamio, et al., 2008; Dunklin, 2012; Elliot \& Larsen, 2010; Green, 2012; Grimes, Meehan, Miller, Mills, Ward, \& Wilkinson, 2011; Livingston, 2009; Lopez, 2013; Persky \& Oliver, 2010; Starr-Glass, 2011; Steele et al., 2010; Zinger \& Cohen, 2010).

Military learners on campuses serving primarily traditional undergraduates were less likely to report having a sense of academic or interpersonal validation from their formal and informal academic interactions with other learners. A large number of military learners, including first-time learners and those who re-enrolled following deployments to conflict zones and combat areas, frequently expressed significant frustration, resentment, and anger in their comments about classmates who they saw as being materialistic, rude, immature, self-absorbed, unappreciative of educational opportunities, or primarily interested in socializing. Specific behaviors associated with those labels including interrupting the instructor, complaining about homework or assignments, or texting and carrying on with others during class. By contrast, the military learners often described themselves as being more worldly, disciplined, mature and serious about their studies. In other instances, military learners' perceptions were more introspective and focused on how old or awkward each felt in the midst of traditional-aged learners who were in some cases, the same ages as the military learners' children. A number of military learners who were no longer on active duty also expressed a sense of isolation or alienation and mourned the loss of the camaraderie they experienced in the military. Aside from a few examples of learners joining fraternities or other student clubs, informal interactions with nonmilitary learners outside of required course activities was minimal (Bauman, 2009; Beatty, 2013; Carne, 2011; Cate, 2011; Diamond, 2012; DiRamio et al., 2008; Livingston, 2009; Lopez, 2013; Rumann and Hamrick, 2010; Steele et al., 2010). Considering that social support and interaction have been referenced in one form or another as important retention variables in virtually every major student persistence and retention theory since Tinto's seminal work (1993), these findings were troubling. 
Consistent with the Schlossberg et al. (1989) 4S model, some military learners turned to internal and external relationships with veterans for assistance in navigating college, peer tutoring, or interpersonal support. Others indicated they were not aware of the availability of veteran student clubs, did not have time to participate, or were simply not interested. (Bauman, 2009; Beatty, 2013; Carne, 2011; Cate, 2011; Diamond, 2012; DiRamio et al., 2008; Livingston, 2009; Lopez, 2013; Rumann and Hamrick, 2010; Steele et al., 2010). In a comparative longitudinal study, Whiteman, Barry, Mroczek and MacDermid Wadsworth (2013) found military learners perceived less peer emotional support compared to nonmilitary learners. However, increases in peer emotional support over time were similar for both groups. Whiteman et al. also found increased peer emotional support to be positively associated with better academic and mental health outcomes, although this finding was stronger for nonmilitary learners. Several studies also found that combat exposure, PTSD, or symptoms consistent with a clinical diagnosis of PTSD influenced military learners' behavior and their perceptions of their social and interpersonal experiences. For example, respondents in Zinger and Cohen's study (2010) reported having difficulty sleeping, controlling their anger or managing their reactions to various stimuli. Some also reported feeling emotionally numb, disconnected and unable to relate to nonmilitary family, friends or other learners. Elliot and Larsen (2011) and Wilson (2014) found that PTSD symptoms were positively correlated with college alienation, relationship strain and alcohol abuse. Cate (2011) also found military learners whose self-reported symptoms met the criteria for PTSD or depression were more likely to experience difficulty socializing outside of class and report feelings of not fitting in.

Formal and informal interactions with nonmilitary learners were perceived to be less problematic and more positive or affirming by military learners who attended classes online or at institutions with larger populations of older nontraditional learners. The learner narratives also suggest that some military learners in these settings perceived themselves more as nontraditional learners rather than as service members or veterans, although the majority of their interactions were still limited to academic activities and assignments (Dunklin, 2013; Grimes, et al. 2011; Starr-Glass, 2011; Steele et al., 2010). The military learner's external community memberships and commitments (namely, military duty requirements and training, other work, and family responsibilities) were primarily responsible for the lack of extracurricular engagement. For example, Cole and Kim (2013) found that military learners spent more hours per week outside of college working or caring for dependents than other learners. Be that as it may, they also found that military learners engaged in the same level of effort or time on task, as measured by the number of weekly hours spent studying and completing course work, as nonmilitary learners.

In a multi-state study of online community college learners using similar engagement measures, Fisher (2010) found no significant difference in the level of effort between online military learners and online nonmilitary learners. Fisher also found that experience with online learning predicted level of engagement in online classes and that military learners in the sample were more likely than their nonmilitary peers to be experienced online learners. Additionally, the military learners also expressed intent to persist more often than the nonmilitary learners. Yet, both Cole and Kim (2013) and Fisher found that military learners were engaged less frequently in reflective or integrative learning activities with faculty or the larger campus community outside of course requirements. The findings indicating lower levels of extra-curricular engagement among military learners were consistent across all institution types in the literature. Nonetheless, military learners on campuses serving primarily traditional undergraduates appeared less likely to report having a sense of academic or interpersonal validation from their formal and informal academic interactions with other learners.

\section{Formal academic experiences}

Formal academic experiences encompass course-specific learning activities, such as attending lectures, reading or engaging with course content, participating in class discussions, completing assignments, studying and taking tests or exams. Combat-related cognitive or psychological conditions were associated with several factors known to influence academic performance. Cate (2011) found that 
military learners reporting symptoms consistent with a diagnosis of PTSD were also eight times more likely to report difficulty focusing during classroom lectures compared to those without PTSD symptoms. Although Barry, Whiteman and MacDiarmid Wadsworth (2012) found that military service history mediated the relationship between PTSD and academic self-efficacy, Vroman and Ness (2014) found that both TBI and PTSD were linked to lower academic self-efficacy. All the same, they found no relationship between the use of self-regulated learning strategies and measures of PTSD or TBI. Noting the relatively high level of academic performance of military learners in the study, as measured by GPA, Vroman and Ness called for additional research examining the potential compensatory effects of self-regulated learning strategies among military learners with PTSD or TBI.

Military learners, including those with some previous college experience, reported experiencing initial difficulties with their coursework or assignment expectations. Across the literature, military learners generally attributed these difficulties to the foreign structure, culture and operations tempo of college; a lack of focus or concentration; rusty study skills; forgotten basic concepts; over-estimating their own abilities and time-management skills; or their need to juggle assignments around military duty/training requirements, work or family responsibilities. They generally attributed their ability to overcome those difficulties to their self-discipline, mission-focus, perseverance or grit acquired through military socialization, training and combat experiences. A few credited the support of faculty members who were veterans or other student veterans (Cate, 2011; Beatty, 2013; Diamond, 2012; DiRamio et al.; 2008, Dunklin, 2013; Green, 2012; Grimes et al., 2011; Livingston, 2009; Lopez, 2013; Rumann \& Hamrick, 2010; Steele et al., 2012).

Further supporting the idea that habitus and capital influence the military learner's academic and interpersonal interactions, perception of validation, and sense of fit is Cate's (2011) finding on the influence of perceived role identity. He found that the extent to which learners perceived themselves as being either more "veteran" or more "student" influenced both their perceptions on their transformations from active duty military to college and the sufficiency of their GI Bill benefits. Those who perceived themselves more as "students" rather than "veterans" were more likely to have a positive perception. For online military learners on active duty, especially those in field roles or forward duty areas "outside the wire," the barriers were frequently situational and included slow to no internet access; communication blackouts; long, harsh, stressful, and often unpredictable work hours; and, on occasion, leaders or instructors who were perceived to be unsupportive or unresponsive (Murray, 2013; Starr-Glass, 2011, 2013).

From the accounts provided in the literature, one can argue that military learners who experienced the greatest sense of dissonance and negation or lack of validation were: a) those who perceived themselves as significantly different from the faculty and other learners; b) those whose experiences with the institutional, academic, and social systems of college were most at odds with their expectations; and c) those who perceived the greatest number of obstacles or barriers to the fulfillment of their goals and commitment. Perceived level of fit was further complicated for some learners by the intersecting of multiple community memberships, role identities, and commitments, prompting various levels of adaptation or, in some cases, isolation. By comparison, research examining the specific situational realities, self-perceived identity profiles, institutional experiences and perceptions of fit for online military learners is significantly lacking. However, observations and first-hand accounts from the field suggest that transitional experiences and situational, institutional, or interpersonal barriers were perceived as less severe or insurmountable (Murray, 2013; Starr-Glass, 2011; 2013).

\section{Institutional Response}

As noted by Shea and Bidjerano (2014), previous persistence models do not reflect institutional responses or adaptations to the needs of learners. Providing degree programs and services to military learners online is one way the institution has adapted to meet the needs of military learners and other nontraditional learners. This section of the review identifies the other ways institutions have adapted or 
customized programs and services to better meet the needs of the military learner. In 2012, the American Council on Education reported an increase in the number of institutions providing or expanding support services to military learners, based on 690 responses received from chief student services administrators (McBain, Kim, Cook, \& Snead, 2012). The majority of responses in 2012 were from public two- and four-year institutions, followed by private non-profit institutions. Counseling, financial aid/tuition assistance, and social events were among the most frequently reported services offered. There were also increases in the number of institutions offering service member/veteran clubs or organizations, support groups or mentoring programs, and dedicated service offices for military learners. A majority of institutions also reported providing counseling/referral to assist with PTSD, while only slightly more than half reported having trained staff able to assist military learners with physical accessibility/accommodation needs. For "invisible" disabilities such as TBI, the number was only 35\%. Utilization rates for various services was mixed, with the most popular services being VA benefits counseling, financial aid and tuition assistance counseling, and academic advising, followed by targeted orientations, academic support or tutoring, career planning and employment assistance.

More recent national data reflecting institutional services for military learners at two-year and four-year Title IV eligible degree granting institutions were collected during the 2012-2013 academic year by National Center for Education Statistics (NCES). The definition of military learners used for the survey included active-duty service members, reservists, members of the National Guard, veterans, and dependents using military or veteran benefits (but not military science courses or ROTC programs). Approximately 844,500 military service members, veterans or dependents were reported at the undergraduate level and 109,500 at the graduate level, with $96 \%$ of institutions reporting they enrolled military learners. The majority of those institutions were also able to identify military learners from GI Bill benefits or admission form questions (Queen \& Lewis, 2014).

A majority of institutions that enrolled military learners also offered some level of customized programs and services for them. For example, more than $85 \%$ provided in-state tuition for active-duty service members and a dedicated web portal for current and prospective military learners. Seventy-five percent or more also provided a designated point of contact (staff or office) for military learners, information on military and nonmilitary sources of financial aid, in-state tuition for veterans immediately upon their return and credit for military training. Fifty percent or more provided targeted communications using email or print materials and college admission fairs. Between $25 \%$ and $49 \%$ provided customized information about or referrals for off-campus medical/health services, financial aid counseling, workstudy opportunities, student veteran clubs, special admission-related events and customized academic advising. Less than $25 \%$ provided the following customized services: orientations, a dedicated social space or lounge, career services or assistance finding non-work-study employment, academic support/tutoring, vet-to-vet mentoring programs, special training for faculty and staff, or mental health counseling and disability services. Fewer than $10 \%$ reported cohort-type courses or sections exclusively for military learners (Queen \& Lewis, 2014).

A 2013 survey of voting National Association of Student Personnel Administrators (NASPA) members at 239 institutions representing all sectors also highlighted core services offered to military learners. For example, $75 \%$ of respondents had at least one dedicated staff resource or office focused on military learners. Those institutions with more than 100 student veterans were also more likely to have a dedicated veterans' office, rather than a single staff person embedded within student affairs. They were also more likely to provide training for faculty, staff and administrators. The results also indicated that data collection, tracking, and analysis on military learner retention and attrition was problematic for about $75 \%$ of the institutions surveyed. Only 5\% could provide data on the effectiveness of their military learner programs, services aimed at improving retention (NASPA Research and Policy Institute, 2013). Other practices included establishing cross-functional work groups or standing advisory committees, seeking input from student veterans, developing first-year learning communities and partnering with government and local community-based groups that provide veterans' services. However, evidence on the 
effectiveness of military learner programs and services implemented since the passage of the Post-9/11 GI Bill has been described as “anecdotal and qualitative” (O’Herrin, 2011, pg. 15).

While most of the institutional services and programs presented in the literature do not represent the "techno-social" institutional adaptations suggested by Shea and Bidjerano (2014), they do align with societal goals for expanding and improving educational access, especially to nontraditional learners. According to the Online Learning Consortium's (OLC) quality framework, the quality of any institution can be judged along five inter-related dimensions: access, scale, faculty satisfaction, student satisfaction and learning effectiveness (Yeo \& Mayadas, 2010). While the OLC promotes the operationalization of this framework to online learning environments, the underlying tenants of each of the five dimensions are, for the most part, learning mode agnostic. Therefore, they can be applied conceptually to online or campus-based learning. From the institutional perspective, the OLC quality pillar of access refers to the means and methods by which learners are able to obtain a higher education credential. A key hallmark of quality access according to OLC is "intuitive navigability." Although some military learners found that their chosen institutions lacked this "intuitive navigability," recent data suggests that many institutions have made efforts to improve access and the college experiences afforded to military learners.

\section{Academic Outcomes}

The attainment of college credentials is closely associated with and contingent upon college retention, persistence, and departure. In Falcone's (2011) proposed persistence model, the learner's perception of his or her academic and interpersonal institutional experiences, outcomes, and the sense of validation they provide influences the learner's sense of "fit" or belonging. Falcone's model posits that sense of perceived fit prompts learners to: a) revise original goals; b) adapt self-perceptions, attributes, commitments, and actions towards the original goal; c) transfer to another institution; or d) leave higher education altogether. A number of researchers have examined individual and environmental variables to determine the extent to which military status impacts various higher education outcome measures. This section summarizes key educational outcomes, including GPA and sense of belonging, learner satisfaction, course completion, time to completion, and actual completion.

In a study on the outcomes of the current generation military learners, Cate (2014a) cites a number of historical reports indicating that WWII generation military learner academic performance, as measured by GPA, was comparable to or better than the academic performance of nonmilitary learners. More recently, Teachman (2007) found that post-Vietnam or Cold-War generation military learners' educational attainment lagged behind that of nonmilitary learners. Cate (2014a) found that Census Bureau data indicated a higher percentage of veterans have completed either some college or an advanced degree compared to nonmilitary learners, although veterans lagged behind nonmilitary learners on the rate of attainment for bachelor's degrees. Cate reported that his analysis of military learners' self-reported GPAs revealed no statistically significant differences among military branches or combat experience. However, active-duty service members reported higher GPAs than activated reservists, who in turn reported higher GPAs than non-activated reservists. Based on effect size, Cate suggested that the positive effect of military training may outweigh the negative effect of PTSD on GPA.

In another comparative analysis examining the predictive effect of student veteran demographic attributes and level of engagement, Durdella and Kim (2010) found that military service was negatively associated with average GPA, but not sense of belonging. Specific factors shown to impact GPAs, including higher family income and being a first-time student, occurred at lower frequencies among student veterans. Factors known to predict lower GPAs, including applied sciences majors and work intensity, were higher among student veterans. On factors associated with sense of belonging, student veteran levels of academic participation and interaction were significantly higher and their levels of academic time and collaborative work somewhat higher. Their level of engagement in other high impact learning activities was lower than that of the nonmilitary learners. The researchers concluded from their 
findings that "veteran effect" did not predict sense of belonging, only GPA. Contrary to Durdella and Kim's findings, Cate's (2014a) findings suggest that "veteran effect," or more specifically, whether the learner identified more as a veteran or as a student, only impacted sense of belonging, but not GPA.

O’Rourke (2013) found that military learner intent to persist was influenced by the following factors: a) perception that efforts were valued by the learner's military unit; b) ease of registration for desired courses; c) satisfaction with overall educational experience; d) stress level; and e) duty status. For example, military learners in his study who were combat veterans scored higher than those without combat exposure on educational satisfaction, goal commitment and degree utility. High school GPA was related to college GPA, but the relationship between military GPA, or the grade point average a veteran received after his or her initial military occupational course and college GPA was stronger. In another study, Hayek (2011) examined the relationship between online student satisfaction and course completion. Using Noel Levitz survey data indicating student satisfaction ratings with institutional services relative to the weight learners placed on their importance, Hayek found that for online military learners enrolled at a military-friendly university, satisfaction with student services was a significant predictor of course completion.

In a predictive analytics study on retention risk models, Barber and Sharkey (2012) found that military status was not predictive at the associate's or bachelor's degree levels. However, it was predictive at the graduate degree level. In a small study that examined military learner time to completion in an online technology management program, McAllen, Downs and Ascani (2013) found that age, gender, number of transfer credits and prior military experience, together, could accurately predict time to completion outcomes, with the target being three years, for $64 \%$ of the learners. The stand-alone variables were not predictive at a statistically significant level.

Operation College Promise's Graduation Probability Indices research project assessed military learner progress toward degree completion at six public four-year institutions and found that military learners pursued courses at a rate comparable to traditional learners, but their average GPA of 3.04 and their semester-to-semester persistence rates were higher. Average utilization rate for university services among the military learners in the sample was 60 percent. Additionally, only one third of the military learners had received academic credit for their military training (Lang \& Powers, 2013). Perhaps the most significant research project to date in terms of sample size and data collection methodology was the Student Veterans of America Million Records project. Using cross-referenced data from the National Student Clearinghouse and the U.S. Department of Veterans Affairs, the researchers found that between 2002 and 2010, the postsecondary degree or certificate completion rate for veterans using GI Bill benefits (excluding dependents) was $51.7 \%$, with most veterans completing their degrees within $4-5$ years. That rate, according to SVA, was comparable to nonmilitary completion rates and dispelled other recent news media accounts suggesting that $88 \%$ of military learners drop out of college (Cate, 2014b).

As evidenced by the findings of the million records research project (Cate, 2014b), current generation military learners have achieved college completion rates comparable to those of other nontraditional learners, in spite of environmental variables unique to the military learner, including: a) the demands of military training and service; b) the reported challenges associated with transitioning from the military to the civilian/academic culture and environment; and c) other confounding variables such as PTSD, TBI and other service-connected disabilities. Most of the research focused on military learner outcomes suggested that military learners adapt by drawing upon the embodied cultural capital—or habitus - and social capital acquired from the military training, such as self-discipline, mission-first focus, and reliance on fellow military learners as transition and persistence strategies. A few studies have also suggested that institutional service response to military learners, including the provision of convenient online course formats and other customized services, contributed to learner satisfaction and persistence. Additional quantitative empirical research is needed to confirm these findings and support data-driven decision-making by institutional leaders so that resources can be properly allocated to scaling the most successful programs and services. 


\section{Discussion/Conclusions}

The military student population is complex and not easily described by any one educational model. The similarities to nontraditional student populations align these learners to specific persistence models, transition theory, and validation theory to frame their college experiences and outcomes. Both nontraditional and military student populations have overwhelmingly moved to online learning modalities. Prior to the release of the Online Learning Special Issue: Serving those who Serve, there was a dearth of research centered on the online military student population. With a majority of military learners now attend college through online learning, it seems likely that veterans will follow suit. Trends in the attendance of the military student population set the stage for scalable studies which are very necessary if these learners are to be better served.

What is needed to advance the next wave of research on military learners and by extension, other nontraditional learners-including those in the student pool of at-risk learners-is a student success model that positions the institution as a responsive learning partner at key junctures during the learner's transition to college and his or her progression through college. This mutually adaptive relational model must also transcend the college as a place paradigm, as technology continues to blur the once sharp distinction between brick and mortar education and predominately online institutions and degree programs. One such framework, focused on asynchronous learning environments, was recently proposed by Shea and Bidjerano (2014), who positioned an "Institutional Adaptation Portfolio" component comprised of online learning environments, learning analytics, and data-driven interventions within the environmental/experiential variables portion of Falcone's (2011) proposed student persistence model. It is conceivable that this model could be further developed to include additional technology-enabled adaptive partnering activity by the institution at the critical juncture of learner entry and at the reevaluation of goals and commitment stage, as Falcone (2011) intended the model to be continuously looping (iterative) with each re-enrollment. Shea and Bidjerano's (2014) updated model represents a starting point in the discussion on "how institutions of higher education might be seen as partners in a transactional adaptation system” (p. 110). Institutions also have a larger role and need to use frameworks to measure quality overall. The Online Learning Consortium's quality framework and Quality Scorecard can provide a rubric for institutions to measure performance.

More research is also needed to understand military learner transition(s) and college choice. Persistence and current methods of tracking learners assume that the first college a learner chooses is where a student should graduate. The persistence data was revealing for military learners. It almost shows a bimodal trend in which first-generation learners often struggle and others with family college experience do better. Very few of the studies look at large populations. There is pioneering work being done by institutions of the Servicemembers Opportunity Colleges to track military learners from a set of institutions through the National Student Clearinghouse (Nadasen, 2014). The purpose of the work has been to track military student success not from the perspective of one institution but rather to understand how many institutions may contribute to student success.

The shift to online learning is compelling for military learners. Yet, the research remains fragmented. A more collaborative approach with those supporting military student populations' (including veterans) funding and the universities involved needs to evolve. The need to optimize the funding is very clear, but unless data can be analyzed in larger sample sizes, it will remain difficult to find interventions or agree to a conceptual model for these populations. 


\section{About the Authors}

Kate Ford is the Director of Information \& Research Analysis for University of Maryland University's Center for Innovation in Learning and Student Success, where she is responsible for environmental scanning and reporting on research, trends, tools, policy issues, and other topics related to learning innovation. During her 16 years with UMUC, Ms. Ford has held a variety of leadership and technical roles focused on academic technology integration, delivery of online instruction, and faculty training. Ms. Ford holds an MBA and Master of Science in Management from UMUC and a Bachelor of Science in Journalism from the University of Maryland, College Park.

Karen Vignare, Ph.D., is Vice Provost and head of Center for Innovation in Learning and Student Success at University of Maryland University College (UMUC). She has been involved in online learning for more than 15 years. Her research has been funded by the Bill \& Melinda Gates Foundation, the Hewlett Foundation and USAID, and she has published and presented on topics ranging from international education and knowledge organization to evaluation and assessment of learning, online learning and blended learning. Before joining UMUC in June 2013, Dr. Vignare was director of project design and implementation at Michigan State University's MSUglobal, where she focused on the use of open educational resources and competency-based approaches in international education, training and development. Dr. Vignare earned a Ph.D. in Computer Technology and Education from Nova Southeastern University, an MBA from the Simon School at the University of Rochester in New York and a BS in Political Science and Economics from Frostburg State University in Maryland.

\section{References}

Allen, E. \& Seaman, J. (2011). Going the distance: Online education in the United States.

Babson Survey Research Group. Retrieved from

http://www.onlinelearningsurvey.com/reports/goingthedistance.pdf

Allen, E. \& Seaman, J. (2013). Changing the Course: Ten Years of Tracking Online Education in the United States. Babson Survey Research Group. Retrieved from http://www.onlinelearningsurvey.com/reports/changingcourse.pdf

Barber, R. \& Sharkey, M. (2012). Course correction: using analytics to predict course success. In Proceedings of the 2nd International Conference on Learning Analytics and Knowledge (pp. 259262). http://dx.doi.org/10.1145/2330601.2330664

Barnhart, D. (2011). The relationship of academic and social integration to veterans' educational persistence (Doctoral dissertation). Retrieved from Proquest Dissertations and Theses Open database http://pqdtopen.proquest.com/pubnum/3433027.html

Barry, A. E., Whiteman, S. D. \& MacDermid Wadsworth, S. M. (2012). Implications of posttraumatic stress among military-affiliated and civilian students. Journal of American College Health, 60(8), 562-573. http://dx.doi.org/10.1080/07448481.2012.721427

Barry, A. E., Whiteman, S. D. \& MacDermid Wadsworth, S. (2014). Student service members/veterans in higher education: A systematic review. Journal of Student Affairs Research and Practice, 51(1), 30-42. http://dx.doi.org/10.1515/jsarp-2014-0003

Bauman, M. C. (2009). Called to serve: The military mobilization of Undergraduates (Doctoral dissertation). Retrieved from Proquest Dissertations and Theses database. (UMI No. 3380873)

Bean, J. P. \& Metzner, B. S. (1985). A conceptual model of nontraditional undergraduate student attrition. Review of Educational Research, 55(4) 485-540. Retrieved from http://www.jstor.org/stable/1170245 
Beatty, P. J. (2013). The transition experiences of re-enrolling student veterans at a public four-year university (Doctoral dissertation). Retrieved from http://rave.ohiolink.edu/etdc/view?acc_num=ohiou1363904403

Bourdieu, P. (1977a). Outline of a theory of practice (R. Nice, Trans.). Cambridge, UK: Cambridge University Press.

Bourdieu, P. (1977b). Cultural reproduction and social reproduction. In J. Karabel and A. H. Halsey (Eds.), Power and ideology in education (pp. 487-511). New York, NY: Oxford University Press.

Bourdieu, P. (1984). Distinction: A social critique of the judgment of taste (R. Nice, Trans.). Cambridge, MA: Harvard University Press.

Bourdieu, P. (1986). The forms of capital. In J. G. Richardson (Ed.), Handbook of theory and research for the sociology of education (pp. 241-258). New York: Greenwood Press.

Braxton, J. M., \& Milem, J. F. (2000). The influence of active learning on the college student departure process. Journal of Higher Education, 71(5), 569-590. Retrieved from http://www.jstor.org/stable/2649260

Bunting, K. A. (2003). Military personnel: Perceptions of their experiences with online learning (Doctoral dissertation). Retrieved from Proquest Dissertations and Theses database. (UMI No. 3102777)

Carne, G. L. (2011). Coming back to college: Middle East veteran student involvement and culture shock (Doctoral dissertation). Retrieved from Proquest Dissertations and Theses database. (UMI No. 3449946).

Cate, C. A. (2011). Student veterans' college experiences: Demographic comparisons, differences in academic experiences, and on-campus service utilization (Doctoral dissertation). Retrieved from Proquest Dissertations and Theses database. (UMI No. 3481950)

Cate, C. A. (2014a). An examination of student veteran completion rates over service eras: An in-depth analysis of the 2010 National Survey of Veterans. Retrieved from http://www.studentveterans.org/images/Documents/SVA\%20Research\%20Brief\%202-1.pdf

Cate, C. A. (2014b). Million records project: Research from Student Veterans of America. Retrieved from http://www.studentveterans.org/what-we-do/million-records-project.html\#data

Choy, S. (2002). Nontraditional Undergraduates: Findings from "The condition of education, 2002". Retrieved from http://eric.ed.gov/?id=ED471077

Church, T. E. (2009). Returning veterans on campus with war related injuries and the long road back home. Journal of Postsecondary Education and Disability, 22(1), 43-52. Retrieved from http://files.eric.ed.gov/fulltext/EJ844250.pdf

Cole, J. S. \& Kim, Y. M. (2013). Student veterans/service members' engagement in college and university life and education. Retrieved from http://www.acenet.edu/newsroom/Documents/Student-Veterans-Service-Members-Engagement.pdf

Covert, C. M. (2002). Soldiers preparing for new careers: An examination of the motivations and barriers associated with postsecondary educational participation of nontraditional students in transition (Doctoral dissertation). Retrieved from http://eric.ed.gov/?id=ED472121

Department of Veterans Affairs (2014) VA campus toolkit handout: Characteristics of student veterans [factsheet]. Retrieved from http://www.mentalhealth.va.gov/studentveteran/docs/ed_todaysStudentVets.html 
Diamond, A. M. (2012). The adaptive military transition theory: Supporting military students in academic environments (Doctoral dissertation) Retrieved from Proquest Dissertations and Theses database. (UMI No. 3504491)

DiRamio, D., Ackerman, R. \& Mitchell, R. L. (2008). From combat to campus: Voices of studentveterans. NASPA Journal, 45(1). Retrieved from http://www.auburn.edu/ diramdc/c2c.pdf

DiRamio, D., \& Jarvis, K. (2011). Special Issue: Veterans in higher education--When Johnny and Jane come marching to campus. ASHE Higher Education Report, 37(3), 1-144. http://dx.doi.org/10.1002/aehe.3703

DOD voluntary education fact sheet: FY2009 (2012, February 21). Retrieved from http://www.dantes.doded.mil/_content/fact-sheets/FactSheetFY09.pdf

DOD voluntary education fact sheet: FY2010 (2012, February 21). Retrieved from http://www.dantes.doded.mil/_content/fact-sheets/FactSheetFY10.pdf

DOD voluntary education fact sheet: FY2011 (2012, February 21). Retrieved from http://www.dantes.doded.mil/_content/fact-sheets/FactSheetFY11.pdf

DOD voluntary education fact sheet: FY2012 (2013, February 28). Retrieved from http://www.dantes.doded.mil/ content/fact-sheets/FactSheetFY12.pdf

DOD voluntary education fact sheet: FY2013 (2013, December 20). Retrieved from http://www.dantes.doded.mil/ content/fact-sheets/FactSheetFY13.pdf

Dunklin, S. B. (2012). The transfer veteran student experience: exploring college choice, transition, and collegiate experiences of veterans (Doctoral dissertation). Retrieved from http://commons.emich.edu/theses/446

Durdella, N. \& Kim, Y. K. (2012). Understanding patterns of college outcomes among student veterans. Journal of Studies in Education, 2(2). Retrieved from http://scholarworks.csun.edu/handle/10211.2/2915

Elliott, M., Gonzalez, C. \& Larsen, B. (2011). US military veterans transition to college: Combat, PTSD, and alienation on campus. Journal of Student Affairs Research and Practice, 48(3), 279-296. http://dx.doi.org/10.2202/1949-6605.6293

Falcone, T. M. (2011). Toward a new model of student persistence in higher education. Paper presented at the annual meeting of the association for the study of higher education, Charlotte, NC November, 2011. Retrieved from http://eric.ed.gov/?id=ED530661

Fisher, K. A. (2010). Student engagement in community college online education programs: an exploration of six constructs with implications for practice. (Doctoral dissertation). Retrieved from http://repositories.lib.utexas.edu/bitstream/handle/2152/ETD-UT-2010-05-952/FISHERDISSERTATION.pdf

Green, L. A. (2012). Identity and meaning making of student veterans transitioning to college (Doctoral dissertation, Texas Tech University). Retrieved from http://hdl.handle.net/2346/46921

Grimes, A., Meehan, M., Miller, D., Mills, S. E., Ward, M. C. \& Wilkinson, N. P. (2011). Beyond the barricade: A holistic view of veteran students at an urban university. Journal of the Indiana University Student Personnel Association, 62-74. Retrieved from http://scholarworks.iu.edu/journals/index.php/jiuspa/article/view/1939

Harkin, T. (July 30, 2014). Is the new GI Bill working? For profit colleges increasing veteran enrollment and federal funds. (U.S. Senate Health, Education, Labor, and Pensions Committee Majority Committee Staff Report). Retrieved from http://www.harkin.senate.gov/documents/pdf/53d8f7f69102e.pdf 
Hayek, C. T. (2011). A nonexperimental study examining online military learner satisfaction and retention (Doctoral dissertation). Retrieved from Proquest Dissertations and Theses database. (3475761)

Hoge, C. W., Castro, C. A., Messer, S. C., McGurk, D., Cotting, D. I., \& Koffman, R. L. (2004). Combat duty in Iraq and Afghanistan, mental health problems, and barriers to care. New England Journal of Medicine, 351(1), 13-22. http://dx.doi.org/10.1056/NEJMoa040603

Horn, L. J. \& Carroll, C. D. (1996). Nontraditional undergraduates: Trends in enrollment from 1986 to 1992 and persistence and attainment among 1989-90 beginning postsecondary students. Postsecondary education descriptive analysis reports. Statistical analysis report. Retrieved from http://eric.ed.gov/?id=ED402857

Lemos Jr, F. F. (2013). Evaluating GPA and Satisfaction Rates for Veteran Populations Transitioning from Combat to College Classroom (Doctoral dissertation) Retrieved from Proquest Dissertations and Theses database. (UMI No. 3595296)

Livingston, W. G. (2009). Discovering the academic and social transitions of re-enrolling student veterans at one institution: A grounded theory (Doctoral dissertation). Retrieved from Proquest Dissertations and Theses database. (UMI No. 3355150)

Lopez, E. S. (2013). The effectiveness of university programs, services, and practices in retaining student veterans transitioning to higher education: Voices of student veterans-A case study analysis approach at two universities (Doctoral dissertation). Retrieved from Proquest Dissertations and Theses database. (UMI No. 3599497)

McAllen, D. K., Downs, G. \& Ascani, H. (2013). The relationship between prior military education and academic performance in an online technology management undergraduate program. In Technology Management in the IT-Driven Services (PICMET), 2013 Proceedings of PICMET'13: (pp. 2498-2501). Retrieved from http://ieeexplore.ieee.org/xpl/mostRecentIssue.jsp?punumber=6624250

McBain, L., Kim, Y. M., Cook, B. J. \& Snead, K. M. (2012). From soldier to student II: Assessing campus programs for veterans and service members. Retrieved from http://www.acenet.edu/news-room/Documents/From-Soldier-to-Student-II-Assessing-CampusPrograms.pdf

Military OneSource (2014, August 12). An overview of voluntary education programs [website]. Retrieved from http://www.militaryonesource.mil/voluntary-education?content_id=275026

Murray, A. T. (2013). Impact of military deployment and distance learning on soldier-students (Doctoral dissertation). Retrieved from Proquest Dissertations and Theses database. (UMI No. 3589602)

Nadasen, Denise. (2014). Retention and graduation rates for military students. University of Maryland University College Analysis of the Fiscal Year 2006 SOC Cohort. Retrieved from www.umuc.edu.

NASPA Research \& Policy Institute (2013). Measuring the success of student veterans and active duty military students. Retrieved from www.naspa.org

National Survey of Student Engagement. (2010). Major differences: Examining student engagement by field of study—annual results 2010. Bloomington, IN: Indiana University Center for Postsecondary Research. Retrieved from http://nsse.iub.edu/NSSE_2010_Results/pdf/NSSE_2010_AnnualResults.pdf

Ness, B. M. \& Vroman, K. (2014). Preliminary examination of the impact of traumatic brain injury and posttraumatic stress disorder on self-regulated learning and academic achievement among 
military service members enrolled in postsecondary education. The Journal of Head Trauma Rehabilitation, 29(1), 33-43. http://dx.doi.org/10.1097/HTR.0b013e3182a1cd4e

O’Herrin, E. (2011). Enhancing veteran success in higher education. Peer Review, 13(1), 15-18. Retrieved from http://www.aacu.org/peerreview/pr-wi11/prwi11 oherrin.cfm

O’Rourke Jr, P. C. (2013). How military service affects student veteran success at community colleges (Doctoral dissertation). Retrieved from http://gradworks.umi.com/35/85/3585006.html

Park, J.H. \& Choi, H. J. (2009). Factors influencing adult learners' decision to drop out or persist in online learning. Educational Technology \& Society, 12(4), 207-217. Retrieved from http://ifets.info/journals/12 4/18.pdf

Parsad, B., and Lewis, L. (2008). Distance Education at Degree-Granting Postsecondary Institutions: 2006-07 (NCES 2009-044). National Center for Education Statistics, Institute of Education Sciences, U.S. Department of Education. Washington, DC. Retrieved from http://nces.ed.gov/pubs2009/2009044.pdf

Persky, K. R. \& Oliver, D. E. (2010). Veterans coming home to the community college: Linking research to practice. Community College Journal of Research and Practice, 35(1-2), 111-120. http://dx.doi.org/10. 1080/10668926. 2011. 525184

Queen, B., and Lewis, L. (2014). Services and support programs for military service members and veterans at postsecondary institutions, 2012-13 (NCES 2014-017). U.S. Department of Education. Washington, DC: National Center for Education Statistics. Retrieved from http://nces.ed.gov/pubs2014/2014017.pdf

Radford, A. W. (2009). Military service members and veterans in higher education: What the new GI Bill may mean for postsecondary institutions. Retrieved from American Council on Education website: http://www.acenet.edu/news-room/Documents/Military-Service-Members-and-Veteransin-Higher-Education.pdf

Radford, A. W. \& Wun, J. (2009). Issue tables: A profile of military service members and veterans enrolled in postsecondary education in 2007-08. Institute for Education Sciences. US Department of Education. NCES, Report, (2009-182). Retrieved from http://nces.ed.gov/pubs2009/2009182.pdf

Radford, A. W. (2011). Military service members and veterans: A profile of those enrolled in undergraduate and graduate education in 2007-08 (NCES 2011-163). U.S. Department of Education, National Center for Education Statistics. Retrieved from http://nces.ed.gov/pubsearch/pubsinfo.asp?pubid=2011163

Rendon, L. I. (1994). Validating culturally diverse students: Toward a new model of learning and student development. Innovative Higher Education, 19(1), 33-51. http://dx.doi.org/10.1007/BF01191156

Rendon, L. I. (2002). Community college puente: A validating model of education. Educational Policy, 16(4), 642-667. http://dx.doi.org/10.1177/0895904802016004010

Rovai, A. P. (2003). In search of higher persistence rates in distance education online programs. The Internet and Higher Education, 6(1), 1-16. http://dx.doi.org/10.1016/S1096-7516(02)00158-6

Rumann, C. B. (2010). Student veterans returning to a community college: Understanding their transitions (Doctoral dissertation). Retrieved from Proquest Dissertations and Theses database. (UMI No. 3403830)

Rumann, C. B. \& Hamrick, F. A. (2010). Student veterans in transition: Re-enrolling after war zone deployments. The Journal of Higher Education, 81(4), 431-458. http://dx.doi.org/10.1353/jhe.0.0103 
Schlossberg, N. K. (1984). Counseling adults in transition: Linking practice with theory. New York: Springer.

Schlossberg, N. K., Lynch, A. Q., and Chickering, A. W. (1989). Improving higher education environments for adults. San Francisco: Jossey-Bass.

Shea, P. \& Bidjerano, T. (2014). Does online learning impede degree completion? A national study of community college students. Computers \& Education, 75, 103-111. http://dx.doi.org/10.1016/j.compedu.2014.02.009

Smole, D. P. \& Loane, S. S. (2008). A brief history of veterans' education benefits and their value (RL34549) [Congressional Research Service Report]. Retrieved from http://www.fas.org/sgp/crs/misc/RL34549.pdf

Starr-Glass, D. (2011). Military learners: Experience in the design and management of online learning environments. Journal of Online Learning \& Teaching, 7(1), 147-158. Retrieved from http://jolt.merlot.org/vol7no1/starr-glass 0311.htm

Starr-Glass, D. (2013). Experiences with military online learners: toward a mindful practice. Journal of Online Learning \& Teaching, 9(3). Retrieved from http://jolt.merlot.org/vol9no3/starrglass_0913.htm

Steele, J. L., Salcedo, N. \& Coley, J. (2010). Service members in school: Military veterans' experiences using the Post-9/11 GI Bill and pursuing postsecondary education. Rand Corporation. Retrieved from http://www.rand.org/pubs/monographs/MG1083.html

Tanielian, T. L. \& Jaycox, L. (2008). Invisible wounds of war: Psychological and cognitive injuries, their consequences, and services to assist recovery (Vol. 1). Rand Corporation. Retrieved from http://www.westga.edu/ vickir/Military/MilitaryIWW/RAND_IWW_20-Chapter\%207.pdf

Teachman, J. (2007). Military service and educational attainment in the all-volunteer era. Sociology of Education, 80(4), 359-374. http://dx.doi.org/10.1177/003804070708000404

Tinto, V. (1993). Leaving college: Rethinking the causes and cures of student attrition (2nd ed.). Chicago: University of Chicago Press.

Tinto, V. (1997). Classrooms as communities: Exploring the educational character of student persistence. Journal of Higher Education, 599-623. http://www.jstor.org/stable/2959965

Tinto, V. (2006). Research and practice of student retention: what next? Journal of College Student Retention: Research, Theory and Practice, 8(1), 1-19. http://dx.doi.org/10.2190/4YNU-4TMB22DJ-AN4W

Vance, M. L., Miller, W. K. (2009). Serving wounded warriors: Current practices in postsecondary education. Journal of Postsecondary Education and Disability, 22(1), 18-35. Retrieved from http://eric.ed.gov/?id=EJ844248

Veterans Benefits Administration. (2014). Post-9/11 GI Bill (Chapter 33) payment rates for 2014 academic year (August 1, 2014 - July 31, 2015). Retrieved from: http://www.benefits.va.gov/GIBILL/resources/benefits_resources/rates/ch33/ch33rates080114.as p

Walpole, M., (2007). Economically and educationally challenged students in higher education: Access to outcomes. ASHE-Higher Education Report Series, 33(3), 1-113. http://dx.doi.org/ $\underline{10.1002 / a e h e .3303}$

Whiteman, S. \& Barry, A. (2011). A comparative analysis of student service member/veteran and civilian student drinking motives. Journal of Student Affairs Research and Practice, 48(3), 297-313. Retrieved from http://www.ncbi.nlm.nih.gov/pmc/articles/PMC3276113/ 
Whiteman, S. D., Barry, A. E., Mroczek, D. K. \& MacDermid Wadsworth, S. (2013). The development and implications of peer emotional support for student service members/veterans and civilian college students. Journal of Counseling Psychology, 60(2), 265-278. http://dx.doi.org/10.1037/a0031650

Wilson, J. D. (2014). The Post 9/11 veteran and adjustment to higher education (Doctoral dissertation). University of Oklahoma. Retrieved from http://hdl.handle.net/11244/10406

Wilson, K. B., Smith, N. L., Lee, A. L. \& Stevenson, M. A. (2013). When the army post is the campus: understanding the social and academic integration of soldiers attending college. Journal of College Student Development, 54(6), 628-642. http://dx.doi.org/10.1353/csd.2013.0087

Wurster, K. G., Rinaldi, A. P., Woods, T. S. \& Liu, W. M. (2013). First-generation student veterans: Implications of poverty for psychotherapy. Journal of Clinical Psychology, 69(2), 127-137. http://dx.doi.org/10.1002/jclp.21952

Yeo, Kee Meng \& Mayadas , Frank, A. (2010). The Sloan-C Pillars: Towards a balanced approach to measuring organizational learning. Journal of Asynchronous Learning Networks, 14(2). Retrieved at http://onlinelearningconsortium.org/read/latest-issue/

Zinger, L. \& Cohen, A. (2010). Veterans returning from war into the classroom: How can colleges be better prepared to meet their needs. Contemporary Issues in Education Research (CIER), 3(1), 39-52. Retrieved from http://www.cluteonline.com/journals/index.php/CIER/article/view/160/153 